\title{
Imagem reflexiva: uma proposta de tipologia para análise visual
}

\author{
Reflexive image: a tipology proposal for visual analysis \\ Filipe Aguiar Cargnin \\ Mestrando em Design pela Universidade Federal de Santa Catarina (UFSC) - filipecargnin@hotmail.com \\ Gabriela Botelho Mager \\ Doutora em Design pela Pontifícia Universidade Católica do Rio de Janeiro (PUC-Rio). Professora da Universidade do \\ Estado de Santa Catarina (UDESC) - gabriela.mager@udesc.br
}

\section{Resumo}

Esta pesquisa estuda o fenômeno da reflexividade, que se refere àquela característica das imagens que, de alguma forma, remetem a si mesmas, seus elementos constitutivos e seu método construtivo, inscrevendo o receptor em seu espaço discursivo. É objetivo desta pesquisa a análise formal e interpretativa das diversas formas de reflexividade, propondo uma tipologia, para a sua classificação, através da apresentação de exemplos, com ênfase nas imagens do Design. Foram identificados dez tipos diferentes de utilização da reflexividade nas imagens. São eles: referência, pastiche, o meio como tema, explicitação dos elementos constitutivos, exposição do método construtivo, paródia, reformulação, serialização, questões de gênero e não-usabilidade. A reflexividade, nas mãos do designer, tem o potencial de ser uma ferramenta criativa e o conhecimento do seu funcionamento é fundamental para o seu uso consciente. A reflexividade desperta a criatividade e pode estimular o olhar crítico acerca das imagens ao nosso redor, contribuindo para o campo projetual em design.

Palavras-chave: Design gráfico. Reflexividade. Imagem. Autorreferência.

\begin{abstract}
This research studies the phenomenon of reflexivity which refers to those features of images that somehow refers to themselves, their constitutive elements and constructive method, placing the receptor in their discursive space. It is the objective of this research the formal and interpretative analysis of the different forms of reflexivity, proposing a typology for its classification, through examples, focusing on graphic and industrial Design images. It was identified ten different types of reflexivity use. They are: reference, pastiche, the medium as a theme, evidence of the constitutive elements, exposure of the construction method, parody, reformulation, serialization, questions of gender and non-usability. Reflectivity in the hands of the designer has the potential to be a creative tool and knowledge of its operation is essential for its conscious use. The reflexivity awakens creativity and can stimulate thinking about the meanings and ways of the images around us, contributing to the design field.
\end{abstract}

Keywords: Reflexitivity. Image. Self-reference. Graphic design. 


\section{INTRODUÇÃO}

Vive-se em um mundo repleto de imagens. Acorda-se com as estampas das cobertas, almoça-se com as imagens da televisão, trafega-se com as imagens da publicidade, trabalha-se com a imagem digital, entretém-se com a imagem cinematográfica e dorme-se com as imagens do inconsciente. Nascida no Paleolítico, a imagem acompanhou as revoluções e hoje mostra-se integrada a praticamente todas as facetas da vida cotidiana das cidades: Vênus de Milo, Guernica. Mickey Mouse, Star Wars, Facebook, só para citar algumas. As imagens não são iguais e possuem um caráter diferenciado, uma especificidade que chama a atenção a quem estiver disposto e preparado a percebê-lo para a sua própria essência de imagem fabricada, para os seus próprios elementos constitutivos (materiais e discursivos), distanciando o receptor da rotina, do olhar desinteressado que paira sobre os objetos do dia-a-dia.

A reflexividade pode se manifestar de diferentes formas e com intensidade e intuitos diversos. A palavra reflexão possui, ainda, outro significado, que é relevante para essa análise: "volta da consciência, do espírito, sobre si mesmo, para examinar o seu próprio conteúdo por meio do entendimento, da razão" (FERREIRA, 1975, p. 1471). Reflexão é meditação, é ponderação. Refletir exige, antes de tudo, distanciamento e retorno. É preciso se distanciar do conteúdo a ser discernido para depois voltar a esse mesmo conteúdo com uma visão diferente.

O objetivo desta pesquisa é estudar o fenômeno da reflexividade no âmbito das imagens, propondo e apresentando uma tipologia para a identificação das diferentes formas reflexivas, de forma a esclarecer e expandir a noção de reflexividade por meio de casos exemplares. No campo do design gráfico é fundamental compreender o tratamento dado à imagem, na tentativa de proporcionar a utilização consciente da ferramenta da reflexividade na atividade projetual, tendo em mente suas determinantes e suas consequências.

Essa pesquisa classifica-se como exploratória e explicativa, de caráter bibliográfico, na medida em que "tem como preocupação central identificar os fatores que determinam ou que contribuem para a ocorrência dos fenômenos" (GIL, 1988, p. 42). Para isto, buscou-se unir a análise formal/interpretativa das diversas formas de reflexividade com a análise de exemplos, propondo 
uma classificação própria de acordo com o tipo da reflexividade baseada em Stam $(1981 ; 2003)$ para as diferentes formas de reflexividade de acordo com o objetivo do seu uso.

Buscou-se fornecer exemplos paradigmáticos do seu uso, com foco nas imagens do design. No entanto, devido ao caráter interdisciplinar do design, buscou-se apreender a imagem por meio de suas diversas manifestações, tendo em vista a crescente convergência e hibridação dos meios visuais. O termo imagem possui diversos usos e significados e é importante destacar que, para este trabalho, imagem diz respeito ao artefato, seja ele representacional ou abstrato, bidimensional ou tridimensional e "embora nem sempre remeta ao visível, toma alguns traços emprestados do visual (...) e depende da produção de um sujeito" (JOLY, 2006, p. 13), que possui uma intenção comunicativa.

Esta classificação foi criada com base nos recursos utilizados pelas imagens para inscrever o receptor em seu espaço discursivo. É importante lembrar que toda categorização é uma generalização, uma visão subjetiva ao mesmo tempo em que fixa elementos em determinados parâmetros, exclui outros que não se encaixam nestes. As categorias aqui apresentadas não pretendem ser totalizantes, mas constituírem formas de organizar e potencializar a análise. As imagens referentes a cada uma das categorias foram escolhidas pela sua exemplaridade, dentre um universo vasto de imagens reflexivas possíveis. Além disso, uma categoria não exclui as outras, ou seja, uma paródia não deixa de ser uma referência. Portanto, uma mesma imagem pode pertencer a mais de uma categoria.

\section{TIPOLOGIA DE IMAGENS REFLEXIVAS}

A classificação apresenta dez tipos de reflexividade, referindo-se à forma pela qual a imagem inscreve o receptor no seu espaço discursivo.

\subsection{REFERÊNCIA}

Do latim, referentia diz respeito ao ato de referir, de contar, de relatar (FERREIRA, 1975). Dentro do domínio das imagens, a referência é uma alusão a uma imagem ou elemento de uma imagem existente. Uma imagem que se refere à outra presentifica o conteúdo desta imagem, trazendo à tona o contexto da imagem referenciada e o sistema de significações no qual esta se insere, chamando a atenção do receptor para si mesma. Um exemplo de referência é o cartaz 
realizado para o 40 aniversário do bombardeio de Hiroshima (Figura 1). Ao utilizar a iconografia e o estilo do gravurista japonês Katsushika Hokusai (Figura 2), o designer McRay Magleby procurou transmitir, por meio do cartaz, a ideia de serenidade, valor relacionado com a cultura oriental.

Figura 1 - Wave of Peace.

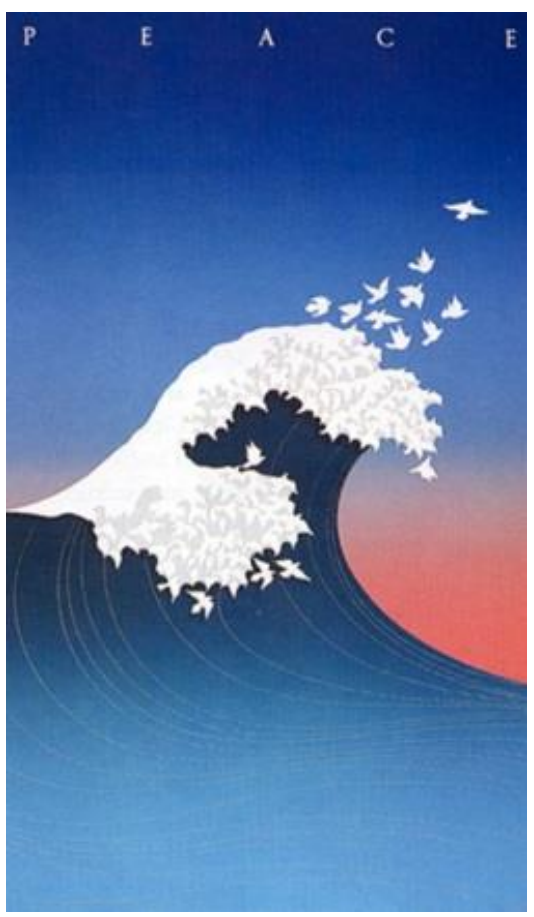

Fonte: Magleby (1985).

Figura 2 - A Grande Onda de Kanagawa.

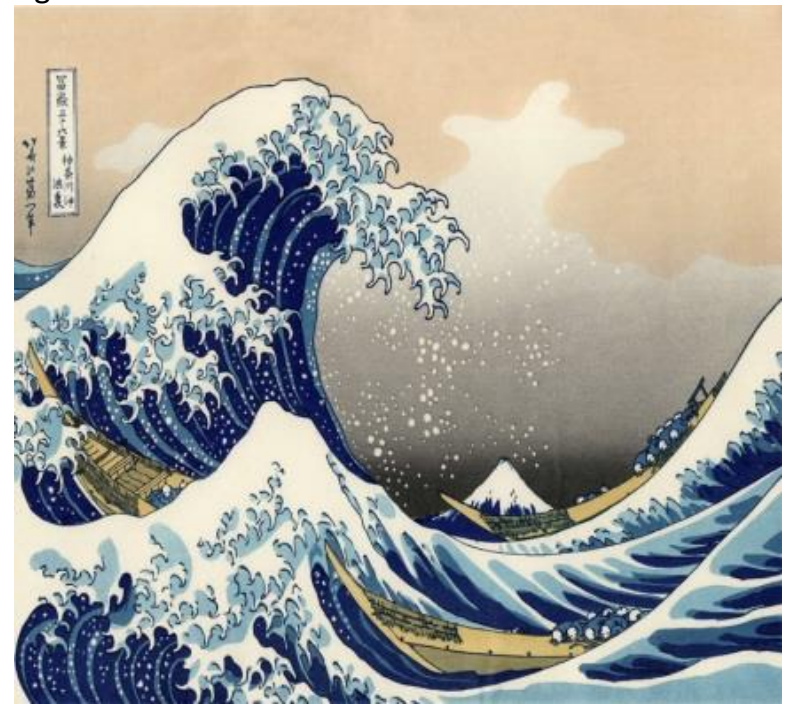

Fonte: Hokusai (1829-1832).

A referência estabelece uma relação entre dois elementos. Esta relação pode se dar de duas formas: homenagem e embasamento. Homenagem é a demonstração de respeito e 
veneração por uma imagem ou um autor. Já, o embasamento é o uso de uma imagem prévia para fundamentar uma afirmação ou agregar significados à imagem que referencia. Wave of Peace, ao mesmo tempo em que homenageia o célebre artista japonês, utiliza-se da imagem da grande onda para intensificar o simbolismo do cartaz, na sua súplica pela paz mundial.

\subsection{PASTICHE}

Enquanto a referência faz menção a uma única imagem ou a um único autor, o pastiche é a apropriação de estilos de épocas ou movimentos culturais diversos em uma única imagem. $\mathrm{O}$ pastiche é uma prática reflexiva na medida em que chama a atenção do receptor, assim como a referência, para o sistema de significações no qual se insere determinada imagem. Para Jameson (1997, p. 44) pastiche é "o imitar de um estilo único, peculiar ou idiossincrático, é o colocar de uma máscara linguística, é falar em uma linguagem morta". Para o autor, o pastiche é uma "prática neutralizada", sem conteúdo crítico, pura citação. Porém, esta é uma visão problemática, na medida em que a simples justaposição de estilos pode trazer à tona novos significados, como os ideogramas chineses, que unem duas ideias para formar um conceito maior, mais amplo do que a simples soma dos anteriores. Além disso, a justaposição pode realçar características que antes eram tidas como lugar-comum e que agora podem ser vistas com outros olhos.

Nos anos 1980, em Nova York, iniciou-se um movimento no design gráfico que possui o pastiche como princípio fundamental. É o movimento retrô, composto por artistas como Paula Scher, Carin Goldberg e Daniel Pelavin (Figura 3). O termo que dá nome ao movimento refere-se a retrógrado, ao olhar para as formas do passado, à retomada histórica.

Era baseado num interesse deslavadamente eclético pelo design europeu modernista da primeira metade do século, um flagrante desacato às regras da tipografia correta e um fascínio por tipos excêntricos e amaneirados projetados e amplamentos usados durante os anos 1920 e 1930 mas praticamente esquecidos após a Segunda Guerra Mundial (MEGGS; PURVIS, 2009, p. 616).

O cartaz Letter as Image/Image as Letter (Figura 3) é exemplar no uso do pastiche pelos integrantes do movimento, devido aos tipos fantasia muito utilizados nas décadas de 1920 e 1930. Outro exemplo de pastiche pode ser encontrado na instalação Re-Braun, projetada por Markus Bader e Max Wolf para a série Bootleg Projects. Nesta série de 2002, os designers se apropriaram 
do estilo simples e despojado de Dieter Rams para a empresa Braun nos anos 1960 e o recontextualizaram para o uso em estações de internet e reprodutores de mp3 (Figura 4). O novo contrasta com o antigo, trazendo novos significados.

Figura 3 - Letter as Image/Image as Letter.

Fonte: Pelavin et al. [s.d.]

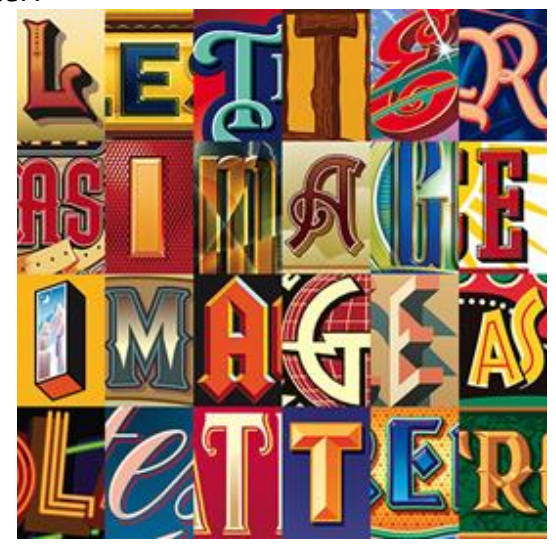

Figura 4 - MP3 jukebox e servidor.

Fonte: Wolf; Bader (2002).

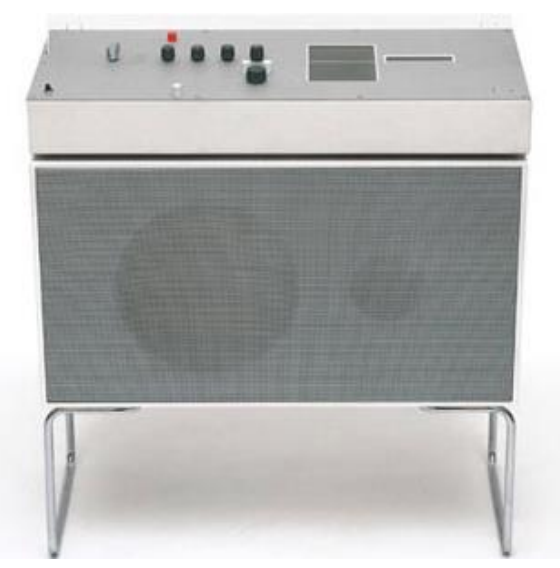

\subsection{O MEIO COMO TEMA}

Outra forma de utilização da reflexividade se dá quando uma imagem possui como tema o seu próprio meio e reflete as características deste. Quando a pintura analisa a pintura, o cinema retrata o fazer cinematográfico, o design pensa seus métodos e a sua prática, no próprio objeto. $\mathrm{O}$ Studio Dumbar é exemplar no uso da reflexividade, refletindo sobre o design enquanto prática 
criativa. Para o pôster de uma exposição de 1982 sobre o De Stijl (Figura 5), movimento de vanguarda da pintura e do design, o grupo quebrou todas as convenções do pôster de museu.

Figura 5 - De Stijl.

Fonte: Dumbar (1982).

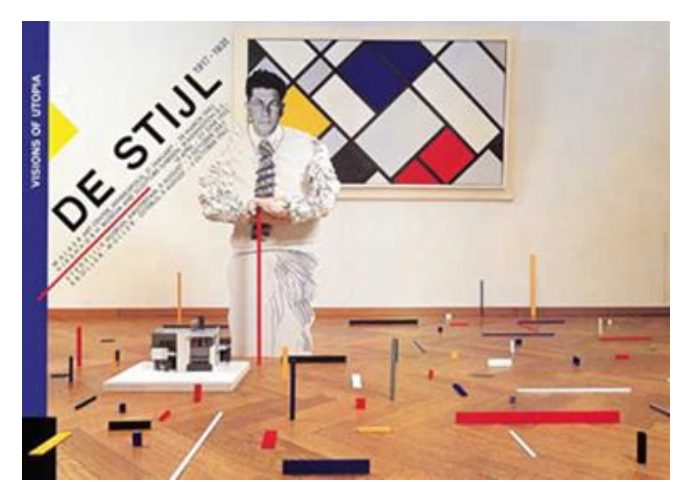

Ao invés de reproduzir uma arte final e adicionar um título e as informações, o grupo montou um cenário no próprio museu e o fotografou. Pendurada na parede estava uma pintura de Van Doesburg (um dos líderes do De Stijl). Na frente, foi colocado um manequim do artista. No chão, foi construída uma maquete arquitetônica no estilo De Stijl e nas cores características do movimento (vermelho, azul e amarelo). Parte do manequim se relaciona com o espaço bidimensional da pintura, a outra parte com o espaço tridimensional da maquete, funcionando como uma ponte entre os dois espaços. "Aqui, o fundador do De Stijl, que introduziu uma das principais características do design gráfico na estética do movimento modernista - a supressão gráfica da profundidade - é ironicamente colocado no espaço tridimensional, sugerido pela perspectiva" (HOLLIS, 2001, p. 209).

No cinema, é Abbas Kiarostami quem faz uso exemplar da reflexividade. No filme Close-up de 1990 (Figura 6), Kiarostami retrata o julgamento de um homem, Hossain Sabzian, que se fez passar por Mohsen Makhmalbaf, célebre cineasta iraniano. O filme é baseado em fatos reais e utiliza as pessoas envolvidas no evento para encenar seus próprios personagens, nos lugares onde os fatos aconteceram. Mistura cenas reais, filmadas durante o julgamento, com cenas construídas, como a cena em que o réu responde às perguntas do interrogatório no tribunal. No final do filme, Kiarostami promove o encontro dos dois homens, Hossain Sabzian, o cidadão iraniano apaixonado por cinema, e Mohsen Makhmalbaf, o cineasta. O cineasta influi no rumo dos acontecimentos e o 
cinema é interrogado. Pode ele fornecer imagens da realidade, imagens verdadeiras? O que é a verdade? E o que é o cinema?

Figura 6 - Close Up, de Abbas Kiarostami.

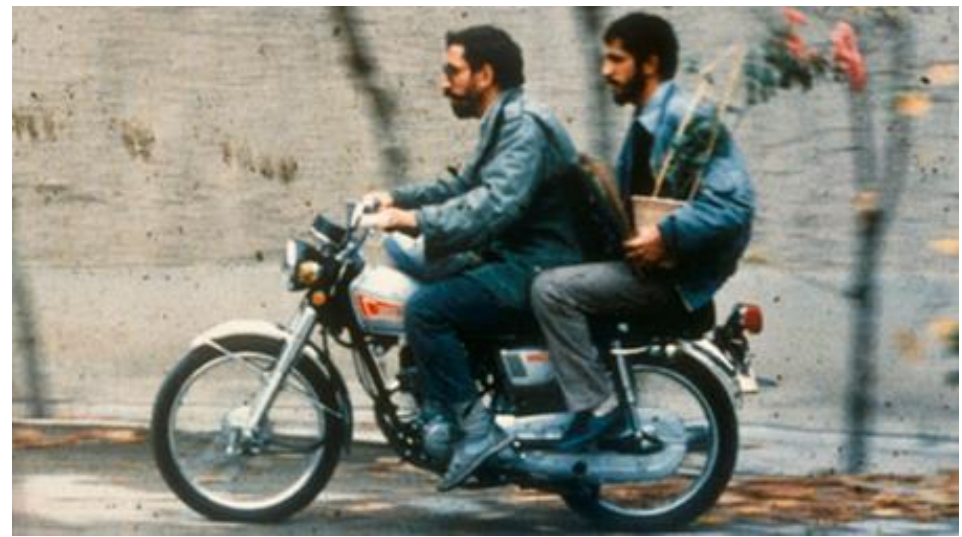

Fonte: Frame extraído do filme Close Up.

\subsection{EXPLICITAÇÃO DOS ELEMENTOS CONSTITUTIVOS}

A reflexividade também se manifesta, quando uma imagem explicita os próprios elementos constitutivos. Isto pode se dar de duas formas: através da simples exposição dos vários elementos que compõe a imagem ou através do exagero, do absurdo. Em Light Abstraction, de 1930 (Figura 7), o fotógrafo Francis Bruguière utilizando múltiplas exposições, leva a imagem ao limite da abstração e descobre o potencial da luz como meio de expressão poética, "em suas abstrações fotográficas, o jogo de luz e sombra se torna o objeto" (MEGGS; PURVIS, 2009, p. 340).

Figura 7 - Light Abstraction, de Francis Bruguière.

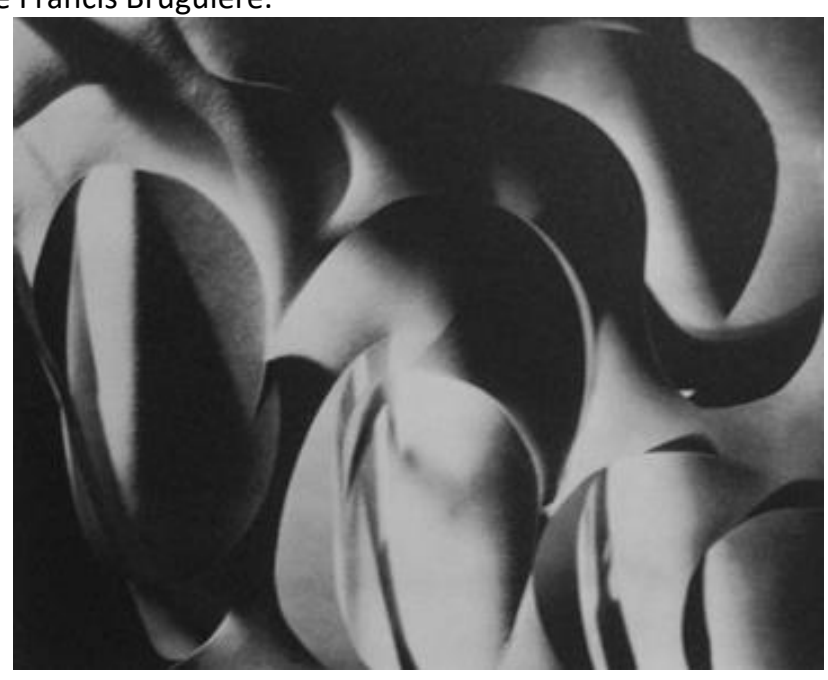

Fonte: MEGGS; PURVIS, 2009, p. 341. 
Figura 8 - Página dupla de Westvaco Inspirations.

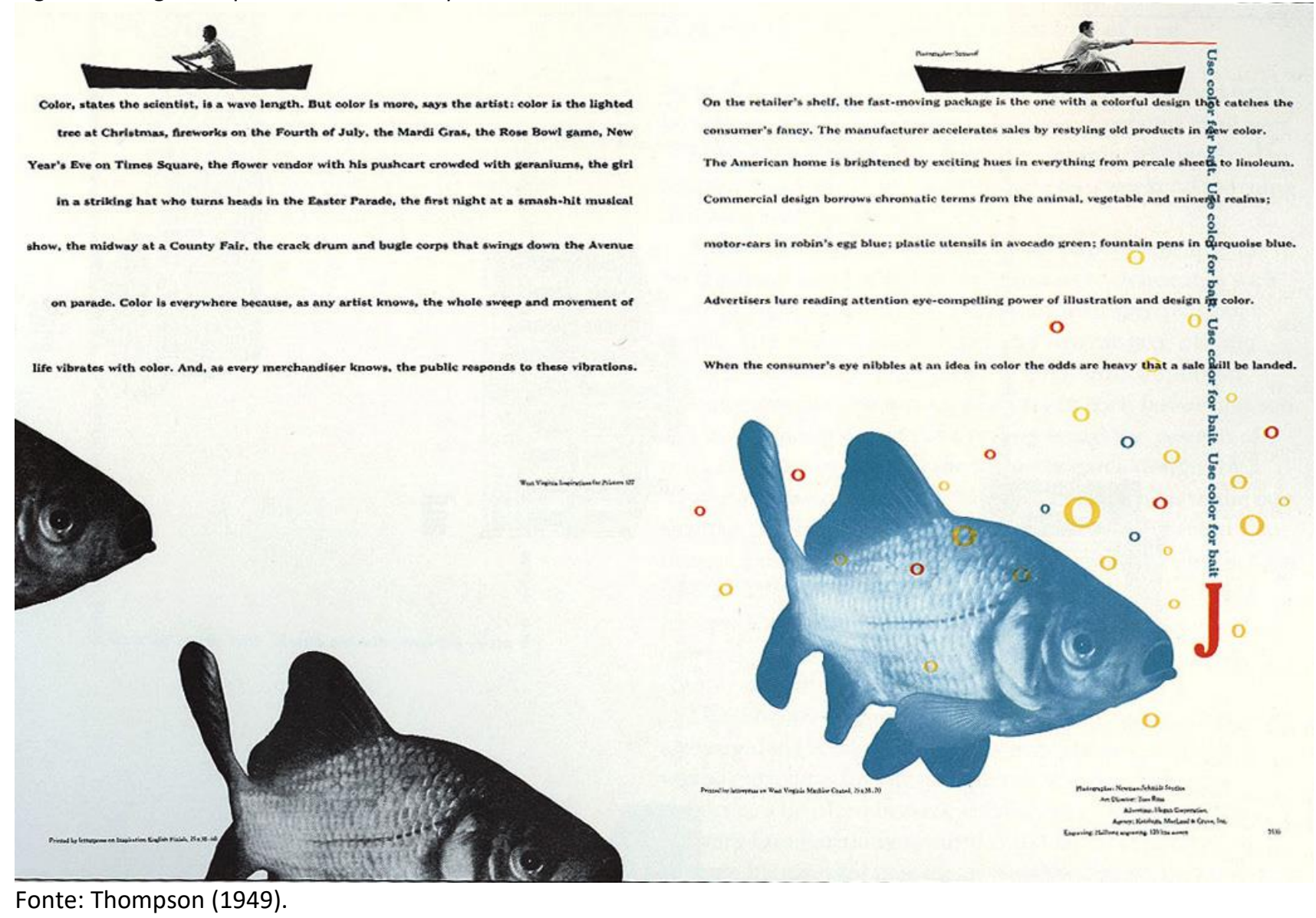

Fonte: Thompson (1949).

Outro caso exemplar de exposição direta dos elementos constitutivos é a página dupla da revista Westvaco Inspirations (Figura 8), da indústria gráfica Westvaco Corporation, diagramada pelo designer Bradbury Thompson, em 1949. As linhas do texto formam ondas, nas quais flutuam dois barcos. As letras "o" formam as bolhas do oceano. A página da esquerda, impressa em monocromia, contrasta com a página da direita, que explicita as quatro cores utilizadas nas impressões com quadricromia (ciano, magenta, amarelo e preto), tanto através do colorido, quanto através do sucesso da pescaria. Um fio tipográfico é utilizado para formar a vara de pescar, enquanto a letra "j" forma o anzol. A imagem possui os seguintes dizeres: "use colour for bait". 0 designer explicita o uso da cor como forma de chamar a atenção para a imagem, além de expor os diversos elementos pelos quais a imagem é composta: tipografia, fios tipográficos, cor e espaço em branco. 
A outra forma pela qual é possível se chamar a atenção para os elementos constitutivos de uma imagem é através do exagero. A palavra kitsch surgiu do alemão kitschen e significa, entre outras coisas, acumulação. O kitsch é o exagero. Nasceu da vontade burguesa de empilhar em suas residências abarrotadas, cada vez mais, objetos sem valor funcional, mas que lhe promove prazer e conforto.

\begin{abstract}
Revela-se em toda a sua pujança durante a ascensão da civilização burguesa, no momento em que ela adota o caráter da afluência, vale dizer, o excesso dos meios em face das necessidades. Em outros termos, uma gratuidade ilimitada que ocorre num certo momento dessa sociedade quando a burguesia impõe suas normas à produção artística (MOLES, 2001, p. 10).
\end{abstract}

Figura 9 - Sofá Safari.

Fonte: Grupo (1967).

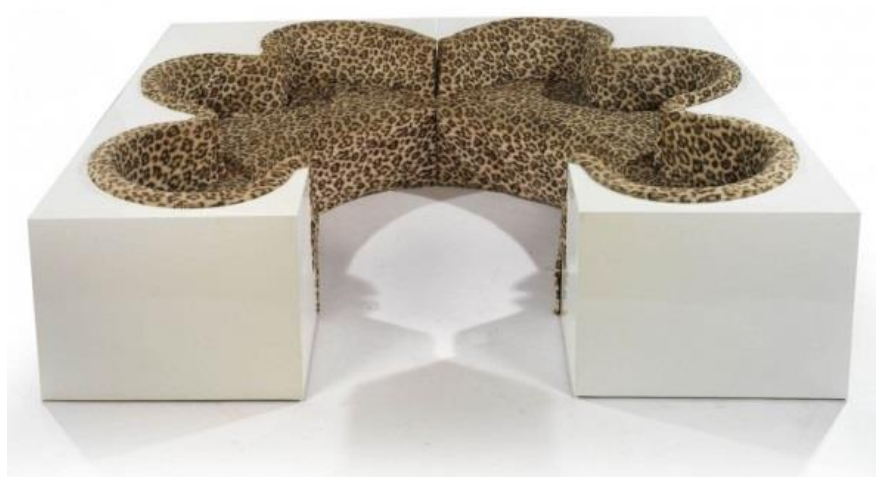

O kitsch é a obra de arte ao alcance de um público médio. A Torre Eiffel miniaturizada vira souvenir. Entre outras, as características do kitsch são: a distorção das grandezas, a grande ornamentação, o uso de cores puras contrastantes, a inadequação formal e a simulação de materiais, como no sofá Safari de 1967 (Figura 9), que além das formas extravagantes, lembram flores, contrastando com o exterior geométrico, utiliza material sintético de forma a simular a pelagem de uma onça.

\title{
2.5 EXPOSIÇÃO DO MÉTODO CONSTRUTIVO
}

A reflexividade pode ser usada de modo a expor o método pelo qual as imagens são construídas. "Na arte reflexiva, a mão do artista é, antes de mais nada, visível” (STAM, 1981, p. 55). Toda imagem passa por uma fase de projeto, mesmo que esta fase dure apenas alguns segundos. 
São realizadas várias escolhas, entre as infinitas possibilidades, de quais elementos (e como) farão parte da imagem final. A reflexividade apresenta essas escolhas, como possibilidades definidas por um sujeito criador, também expondo no processo o próprio sujeito e as técnicas utilizadas. Para uma brochura de divulgação de livros da Bauhaus de 1927 (Figura 11), o designer e professor László Moholy-Nagy reuniu os próprios tipos de impressão que compõem a imagem tipográfica, explicitando o processo de impressão, que se utiliza de clichês reunidos em blocos para formar as palavras e as frases. Além disso, reproduziu a inversão que ocorre no processo de impressão, espelhando o lado esquerdo da fotografia.

Figura 10 - Brochura para livros da Bauhaus, de László Moholy-Nagy.

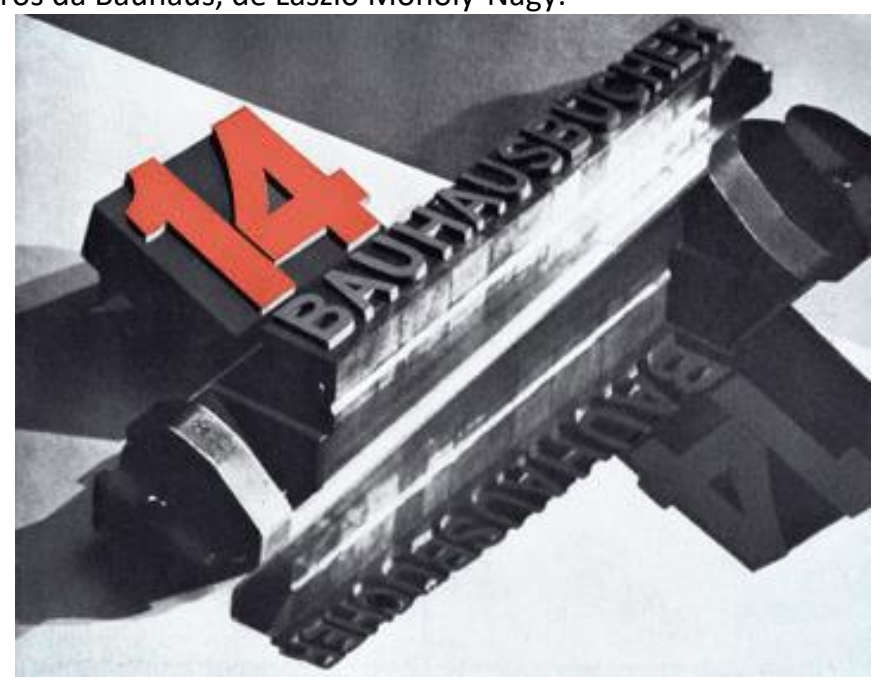

Fonte: HOLLIS, 2001, p. 14.

Nos spots publicitários de 2007 (Figura 11), da Neuf Cegetel, empresa francesa de telefonia móvel, os publicitários discutem entre si a forma de criar uma propaganda efetiva para a marca. A discussão acaba por constituir a própria propaganda exibida na tela. Um dos publicitários indaga o outro, não entendera o conceito para o novo anúncio televisivo. O colega responde: um grande logo e repetição. A marca aparece na tela e as palavras ditas pelo publicitário passam a ser repetidas várias vezes. A publicidade se coloca dentro da publicidade, expondo os seus métodos. Para Gilles Lipovetsky, a memorização não é o mais importante, mas sim "divertir, surpreender e seduzir um consumidor empanturrado, tornando-o cúmplice das mensagens propostas" (LIPOVETSKY, 2009, p. 250). Busca-se uma relação de conivência entre o receptor e o publicitário. O 
público não se ilude com o que a publicidade lhe apresenta, assim como a publicidade não se ilude a ponto de pensar que consegue enganá-lo.

Figura 11 - Bobobox, spot publicitário da Neuf Cegetel.

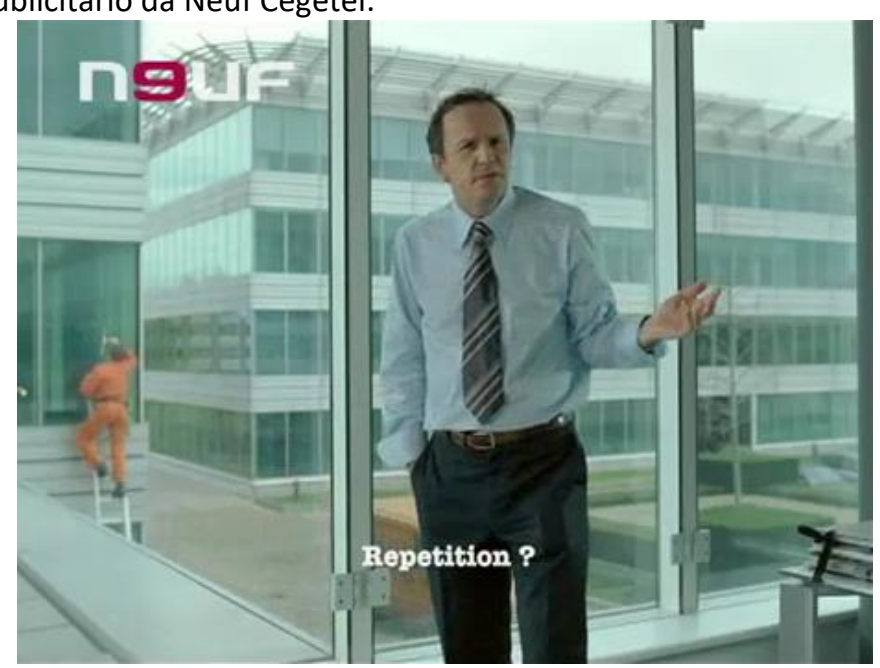

Fonte: www.youtube.com/watch?v=YO_u67met-A

\subsection{PARÓDIA}

A paródia é a imitação irônica de determinada obra ou estilo, de modo a, através da exposição das convenções e limites deste estilo, fornecer um juízo negativo. É uma maneira de o criador utilizar o seu repertório cultural de forma crítica, desvencilhando-se de formas arcaicas, que ainda estão presentes no seu tempo. "Podemos argumentar que a paródia surge, justamente, quando um artista já não mais acredita nas convenções artísticas de seu tempo, pois percebe que elas já não mais correspondem às convenções sócio-históricas que as encerram" (STAM, 1981, p. 29). Além disso, a paródia chama a atenção para a intertextualidade ${ }^{1}$ de todas as imagens, que são constituídas de fragmentos de fórmulas e variações dessas fórmulas, e se inserem dentro de uma cultura que as influencia e é por elas influenciada. Os códigos e a linguagem dos quais a imagem surge, antecedem-na e conformam-na através de um processo sutil de disseminação, seja este consciente ou não. Por isso, a simples referência a outra imagem, já constitui uma autorreferência, por chamar a atenção para uma característica que é integrante de todas as imagens, a intertextualidade.

${ }^{1}$ Cf. STAM, 2003. 
No cartaz para uma exposição do Grapus (Figura 12), os designers do grupo utilizaram a paródia para unir imagens paradigmáticas de certos momentos históricos em um mesmo cartaz que ambicionava retratar as disposições irônicas do grupo diante do respeito às convenções nas práticas imagéticas.

Figura 12 - Cartaz da exposição do grupo Grapus.

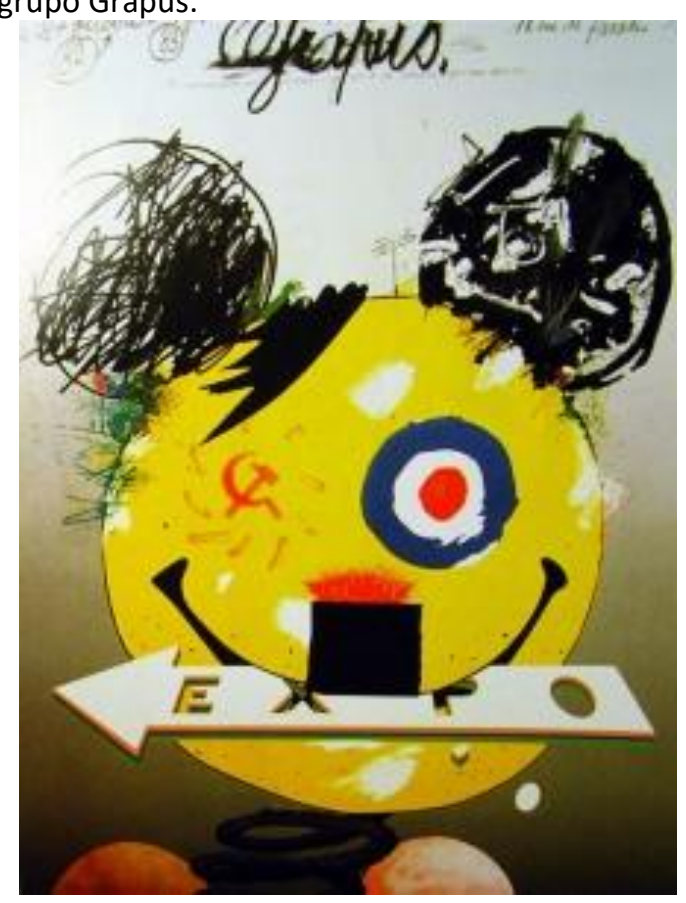

Fonte: Exposition Grapus (1982).

\subsection{REFORMULAÇÃO}

Reformulação é a apropriação de uma imagem anterior para a criação de uma nova. Remake. Re-design. O fato da infração, ou não, aos direitos autorais não é o objetivo deste estudo, mas o que interessa é que toda reformulação remete à imagem anterior e ao seu contexto. No processo de apropriação, são retidas algumas características da imagem anterior, enquanto outras são transformadas ou expandidas. Ao reformular uma imagem, muda-se o contexto no qual esta se insere e, portanto, são necessárias adequações. Além disso, toda interpretação implica em conformação aos imperativos subjetivos da pessoa que a interpreta. Em Las Meninas de 1957 (Figura 13), Pablo Picasso utiliza-se da obra homônima de Velázquez para refletir sobre a história da pintura. Em seu largo estudo sobre a forma, ritmo e movimento, por meio da interpretação dos clássicos, propõe novas formas de se perceber o motivo a ser pintado. 
Figura 13 - Pablo Picasso. Las Meninas. Óleo sobre tela, 194 x 260cm. Barcelona, Museu Picasso.

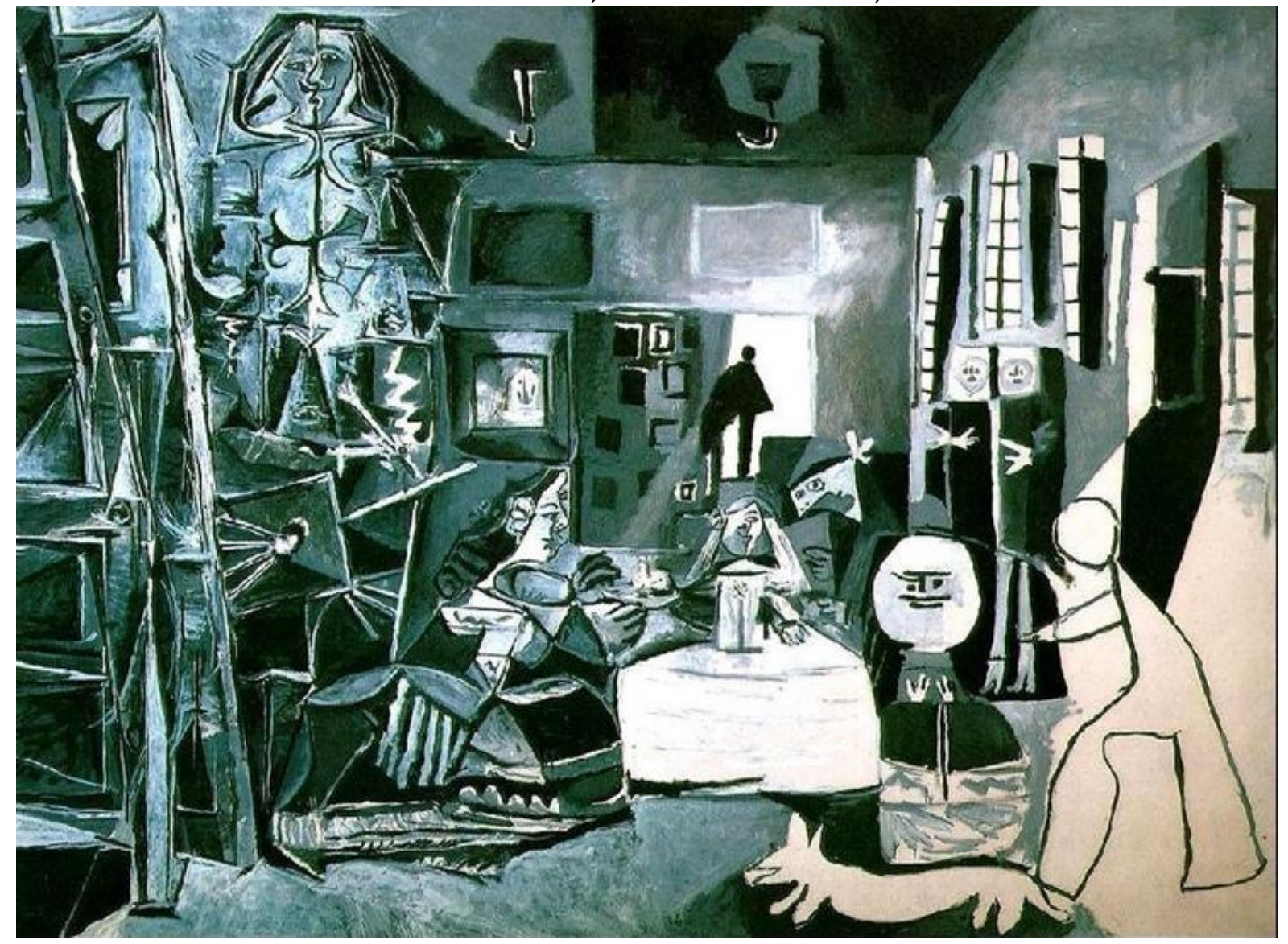

Os pôsteres exerceram enorme influência nos tempos de guerra. Para o serviço de alistamento britânico, Alfred Leete, utilizando-se da imagem do ministro da guerra britânico apontando para o receptor da mensagem, criou um cartaz que foi amplamente copiado (Figura 14). Nos Estados Unidos, o ilustrador James Montgomery Flagg se apropriou do cartaz de Leete e o reformulou para o contexto americano da Primeira Guerra Mundial, trocando o retrato do ministro da guerra britânico por um autorretrato (Figura 15). No contexto dos apelos à paz e ao desarmamento, na Guerra do Vietnã, o Comitê para Desacreditar a Guerra criou um cartaz que se baseava no de Flagg (Figura 16). Como se pode perceber, a reformulação quando crítica se aproxima da paródia. 
Figura 14 - Cartaz inglês para incentivar o recrutamento militar na Primeira Guerra Mundial.

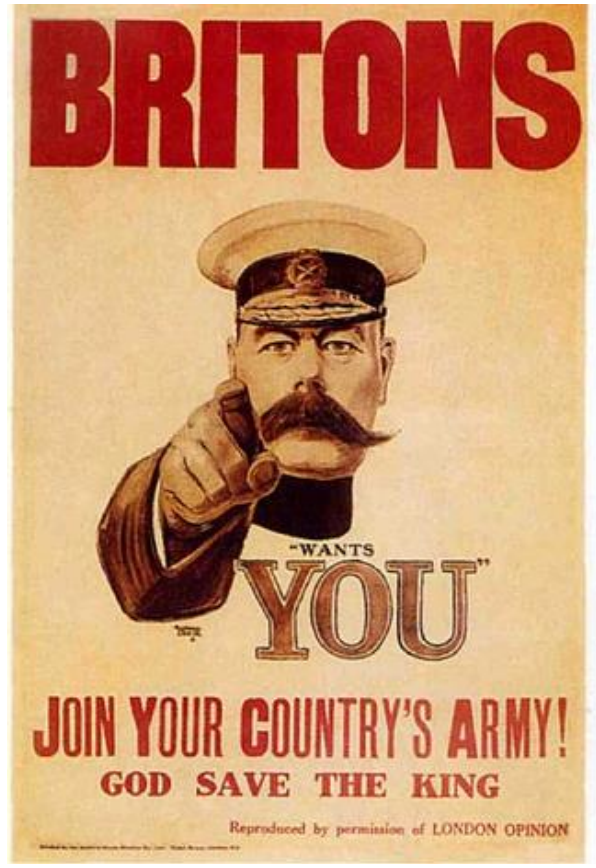

Fonte: Leete (1914).

Figura 15 - Cartaz americano para incentivar o recrutamento militar na Primeira Guerra Mundial.

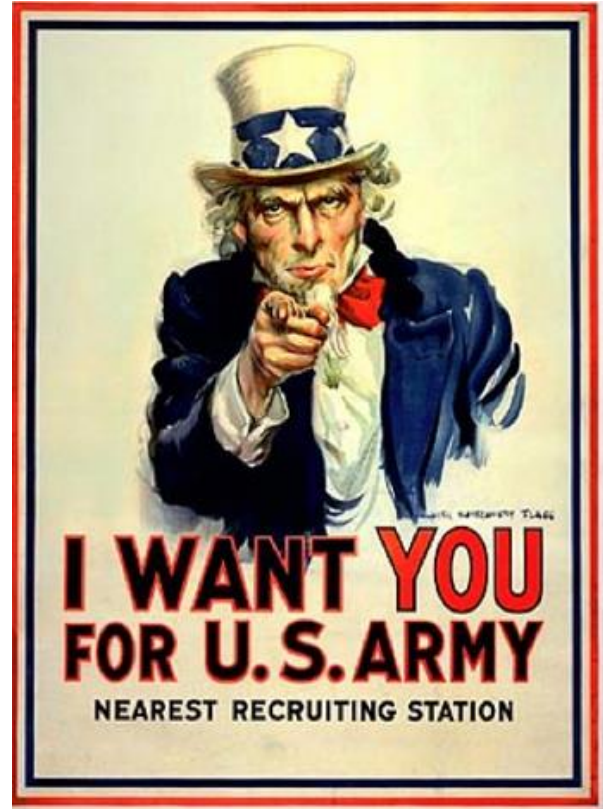

Fonte: Flagg (1917). 
Figura 16 - Cartaz para contra a Guerra do Vietnã.

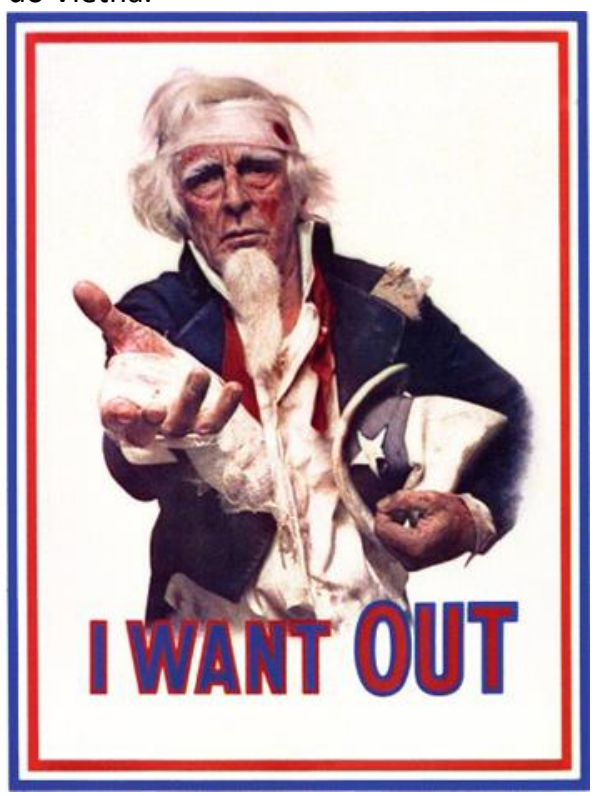

Fonte: Comitê (1971).

\subsection{SERIALIZAÇÃO}

A serialização age segundo uma lógica comercial, que busca explorar ao máximo um produto ou ideia de sucesso. Possui caráter reflexivo, na medida em que a imagem toma como referencial outra imagem já interiorizada no repertório do público consumidor. É muito comum no cinema, onde vemos surgir as trilogias e tetralogias. São reutilizados elementos dos filmes anteriores, como os personagens, o figurino, a história, os temas e a música, inscrevendo o novo filme no universo previamente criado. Um dos filmes mais marcantes que obteve estrondoso sucesso comercial e formou uma série, é o filme Guerra nas Estrelas, de 1977, dirigido por George Lucas. Além do cinema, a série se expandiu para outros formatos, como os videogames e os desenhos animados. No design, a serialidade pode ser exemplificada por conjuntos de objetos tratados de forma a serem dotados de uma unidade semântica, onde cada um deles faz referência aos outros e ao todo, como é o caso do conjunto de chá e café Piazza (Figura 17), criado em 2001, pelo designer Michael Graves, que visto de cima lembra a imagem de uma praça italiana com edifícios ao redor. 
Figura 17 - Tea \& Coffee Piazza de Michael Graves (1983).

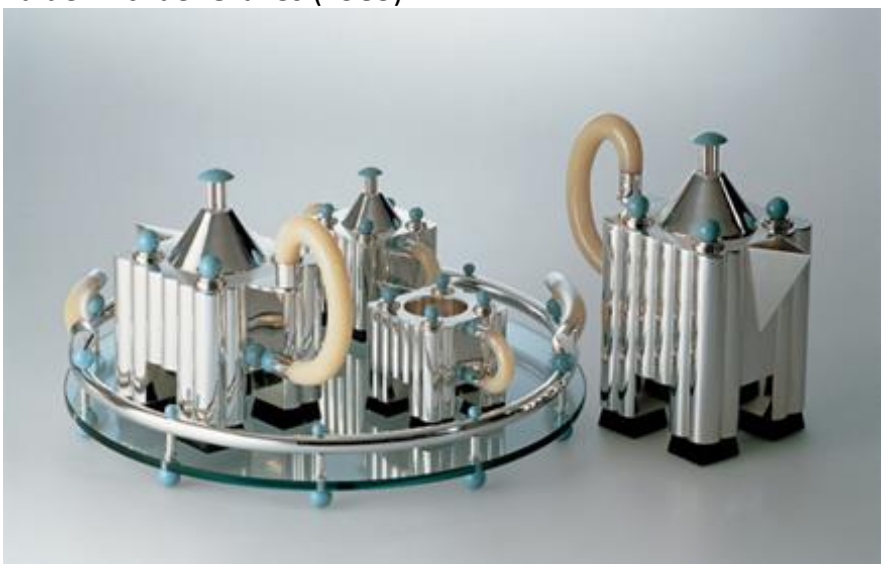

Fonte: Foto ๑ Carlo Lavatori, Archivio Alessi

\subsection{QUESTÕES DE GÊNERO}

Gênero é um conjunto de convenções para a criação de determinadas imagens, estipulando os temas a serem tratados, a estrutura e as características formais da composição. A reflexividade surge, quando as convenções inerentes a um gênero são criticadas e os seus limites são explorados. Deste modo, "ao introduzir defasagens sutis e refinadas variações em relação às expectativas supostas, o jogo das alusões internas [...] autoriza a percepção desprendida e distanciada" (BOURDIEU, 2003, p. 141). Além disso, a mistura de gêneros instaura uma tensão que nos força a refletir sobre a natureza do gênero em si e nos torna conscientes de suas convenções e de como a realidade é por ele mediada.

Rango (Figura 18), animação de Gore Verbinski, de 2011, é exemplar no uso reflexivo do gênero western, o gênero cinematográfico por excelência. No western, o cowboy valente e solitário - caracterizado pelo figurino típico - é retratado em sua jornada pelo ambiente selvagem e árido dos desertos do oeste norte-americano. No filme, o cowboy é um camaleão medroso que usa uma camiseta floral. Na medida em que ao desenrolar a história, a personagem e a narrativa se conformam aos ditames do gênero, a animação se utiliza de outras formas para distorcer as convenções. Como na cena em que o protagonista caminha em direção a uma grande lua, que parodia os finais clássicos do gênero, em que o cowboy segue em direção ao sol se pondo no horizonte. 
Figura 18 - Rango, de Gore Verbinski.

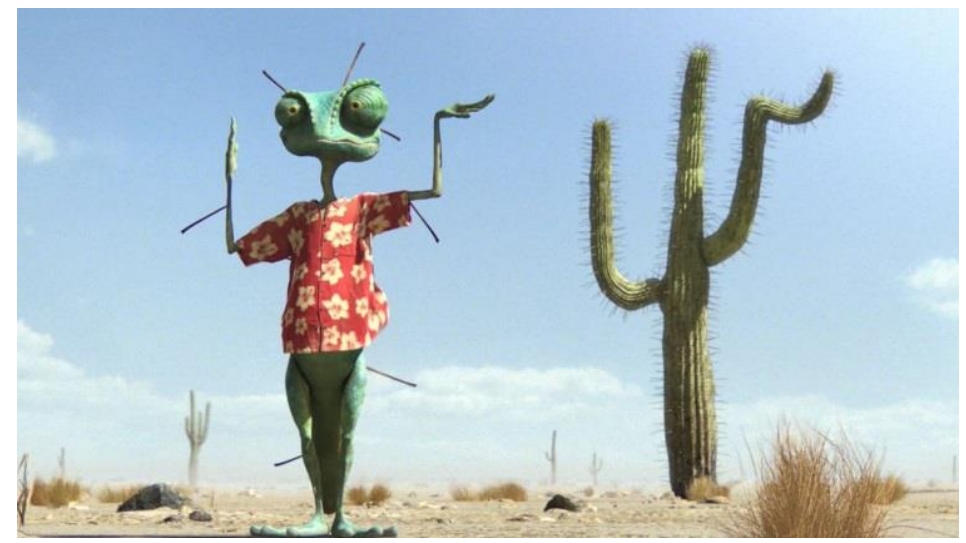

Fonte: Frame extraído do filme.

Os gêneros também estão presentes em outras imagens, além da cinematográfica. No design de mobiliário, por exemplo, existem convenções que estipulam as características dos móveis nos diferentes espaços da casa, características estas que deixam visíveis, com uma simples mirada, o local a qual os objetos se destinam. Objetos como a Chaleira Train Whistle (Figura 19), criada em 1983, pelo designer Richard Sapper, questionam essas convenções ao trazer o universo dos transportes ferroviários para a cozinha (cujos objetos geralmente possuem formas mais orgânicas).

Figura 19 - Chaleira Train Whistle.

Fonte: Sapper (1983).

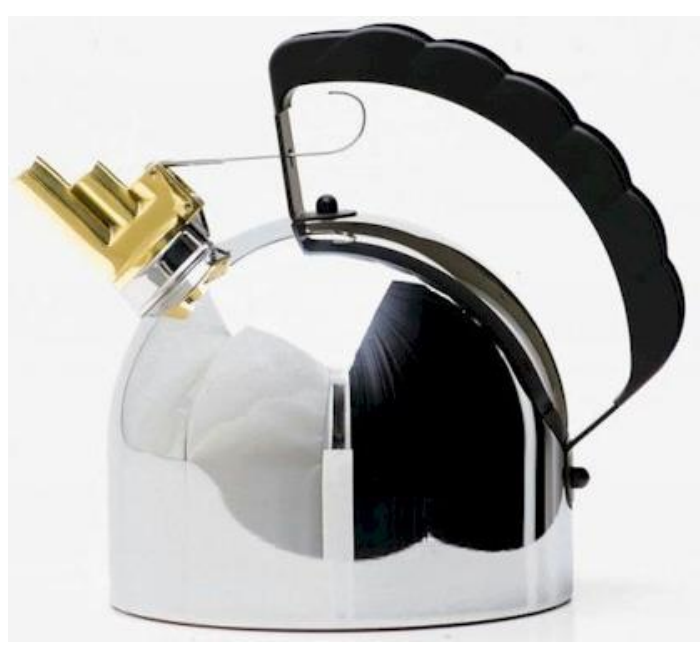

\subsection{NÃO-USABILIDADE}

Esta categoria diz respeito àquelas imagens que "devem" possuir grande valor de uso. $\mathrm{O}$ discurso do design, por exemplo, é permeado pelo aspecto da funcionalidade. "A forma segue a 
função", célebre frase de Louis Sullivan, por muito tempo, conduziu a prática do design no mundo todo. Bürdek, em sua tentativa de delimitação da profissão, sugere alguns problemas que o design deve sempre atender. Entre eles, está: "priorizar a utilização e o fácil manejo de produtos" (BÜRDEK, 2006, p. 16). Já, Hollis, no âmbito do design gráfico, estipula três funções básicas para os objetos do design: identificar, informar e promover (HOLLIS, 2001). Porém, alguns objetos distorcem o seu valor de uso, de forma a aumentar os valores estéticos e semânticos, refletindo sobre a própria história do design e seus preceitos. Em seu catálogo Objetos Inviáveis, de 1969, o francês Jacques Carelman desenvolveu vários objetos que seriam impossíveis de se usar, como a Chaleira para Masoquistas (Figura 20), que ao verter o líquido quente, queimaria a mão da pessoa que a utilizasse.

Figura 20 - Chaleira para Masoquistas.

Fonte: Carelman (1990).

\section{CONSIDERAÇÕES FINAIS}

Nesta pesquisa, buscou-se aprofundar o conhecimento sobre a reflexividade estudando as diferentes manifestações da mesma nas imagens de arte e design. Referência, paródia, pastiche e serialidade foram apenas algumas das manifestações estudadas. No entanto, o design gráfico se beneficia com o uso da reflexividade? Esta é uma pergunta difícil e não se pretende responder aqui de modo definitivo. Devido ao fato da reflexividade necessitar, pela parte do receptor, de códigos para a sua compreensão, o uso extensivo da reflexividade pode levar à elitização do design gráfico, 
cuja compreensão se restringiria a um pequeno círculo de seletos - como aconteceu em grande parte com a arte contemporânea. Porém, a noção de reflexividade trabalhada aqui é bastante abrangente. Acredita-se que certas formas de reflexividade necessitam de códigos que são de amplo conhecimento da maioria das pessoas, que estão cada vez mais em contato com imagens dos mais variados tipos disseminadas pela mídia. Além disso, a produção em série vem dando lugar aos nichos de mercados, onde se cria imagens para um público específico e em que a criatividade passa a ser um diferencial importante nas vendas dos produtos. "El resultado es un nuevo énfasis en la innovación como necessidad principal para la supervivencia competitiva, que depende todo dela creatividad" (HESKETT, 2008, p. 115). A reflexividade desperta a criatividade e pode estimular a reflexão acerca das imagens.

A reflexividade, nas mãos do designer, tem o potencial de ser uma ferramenta criativa e o conhecimento do seu funcionamento é fundamental para o seu uso consciente. Esta proposta de tipologia teve como objetivo fornecer ao designer um conjunto estruturado de procedimentos e elementos relacionados com a reflexividade, incentivando-o a combinar e experimentar as diversas formas de reflexividade apresentadas, além de outras que possam existir, na criação de suas imagens e em seus projetos. Além disso, ao utilizar a reflexividade, o designer é estimulado a pensar criticamente as suas próprias criações e seus métodos, contribuindo para um maior entendimento da profissão, o que é muito importante em um mundo tão imagético, como este do século XXI. Pensar a imagem é, cada vez mais, refletir sobre a realidade cotidiana.

\section{REFERÊNCIAS}

BOURDIEU, Pierre. A economia das trocas simbólicas. 5. ed. São Paulo: Perspectiva, 2003.

BÜRDEK, Bernhard E.. Design: história, teoria e prática do design de produtos. São Paulo: E. Blucher, 2006.

CARELMAN, Jacques. Catàleg d'objectes impossibles. [s. I.]: Aura, 1990.

CLOSE-UP. Produção de Abbas Kiarostami. Estados Unidos: Criterion, 1990. DVD (98 min.): Ntsc, son., color.

COMITÊ para Desacreditar a Guerra. Cartaz para contra a Guerra do Vietnã. 1971. Disponível em: <http://www.media-studies.ca/articles/images/sam_out.jpg>. Acesso em: 07 jul. 2018. 
DUMBAR, Studio. De Stijl. 1982. Disponível em: <https://s-media-cacheak0.pinimg.com/600x315/b1/89/4a/b1894ad70889c070f03f7e7ba953c730.jpg>. Acesso em: 10 jul. 2018.

EXPOSITION Grapus. 1982. Disponível em:

<jpdubs.hautetfort.com/album/affiches_et_affichistes/Grapus(1982).html>. Acesso em: 10 jul. 2018.

FERREIRA, Aurélio Buarque de Holanda. Novo dicionário da língua portuguesa. 2. ed. Rio de Janeiro: Nova Fronteira, 1975.

FLAGG, James Montgomery. Cartaz americano para incentivar o recrutamento militar na Primeira Guerra Mundial. 1917. Disponível em:

<https://nahistoriadehoje.wordpress.com/2016/09/07/nasce-o-termo-tio-sam/>. Acesso em: 10 jul. 2018.

GIL, Antonio Carlos. Como elaborar projetos de pesquisa. São Paulo: Atlas, 1988.

GRUPO Archizoom. Sofá Safari. 1967. Disponível em: <https://s-media-cacheak0.pinimg.com/736x/74/0d/2c/740d2cd15fabca9a88a8c5dbada7fb64.jpg >. Acesso em: 10 jul. 2018.

HESKETT, John. El diseño en la vida cotidiana. Barcelona: Gustavo Gili, 2008.

HOKUSAI, Katsushika. A Grande onda de Kanagawa. 1829-1832. Disponível em: <http://www.artwallpaper.net/artist/hokusai-katsushika/03/Hokusai-Katsushika.jpg>. Acesso em: 10 jul. 2018.

HOLLIS, Richard. Design gráfico: uma história concisa. São Paulo: Martins Fontes, 2001.

JAMESON, Frederick. Pós-modernismo: a lógica cultural do capitalismo tardio. 2. ed. São Paulo: Ática, 1997.

JOLY, Martine. Introdução à análise da imagem. 11. ed. Campinas: Papirus, 2006.

LEETE, Alfred. Cartaz inglês para incentivar o recrutamento militar na Primeira Guerra Mundial. 1914. Disponível em: <https://nahistoriadehoje.wordpress.com/2016/09/07/nasce-o-termo-tiosam/>. Acesso em: 10 jul. 2018.

LIPOVETSKY, Gilles; SERROY, Jean. A tela global: mídias culturais e cinema na era hipermoderna. Porto Alegre: Sulina, 2009.

MAGLEBY, McRay. Wave of peace. 1985. Disponível em: <www.don.citarella.net/wpcontent/uploads/2007/04/I_waveofpeace.jpg>. Acesso em: 10 jul. 2018. 
MEGGS, Philip B.; PURVIS, Alston W. História do design gráfico. São Paulo: Cosac \& Naify, 2009. MOLES, Abraham A. O kitsch: a arte da felicidade. 5. ed. São Paulo: Perspectiva, 2001.

PELAVIN, Daniel et al. Letter as image/image as letter. [s.d]. Disponível em:

<www.tdc.org/events/2007events/letterimage.png>. Acesso em: 23 mar. 2016.

RANGO. Produção de Gore Verbisnki. São Paulo: Paramount Pictures, 2011. DVD (107 min.): Ntsc, son., color.

SAPPER, Richard. Chaleira Train Whistle. 1983. Disponível em:

<http://www.archiexpo.com/pt/prod/alessi-spa/product-149476-1661578.html>. Acesso em: 10 jul. 2018.

STAM, Robert. Do texto ao intertexto. In: STAM, Robert. Introdução à teoria do cinema. Campinas: Papirus, 2003.

STAM, Robert. 0 espetáculo interrompido: literatura e cinema de desmistificação. Rio de Janeiro: Paz e Terra, 1981.

THOMPSON, Bradbury. Página dupla de Westvaco Inspirations. 1949. Disponível em: <citrinitas.com/history_of_viscom/images/modernism/bradthomp-1949.jpg>. Acesso em: 10 jul. 2018.

WOLF, M.; BADER, M. Bootleg objects: series sound. 2002. Disponível em: <http://bootlegobjects.com/objects_sound.htm>. Acesso em: 09 jul. 2018. 